\title{
Ekumenika as Wetenskaplike Dissipline en die Verhouding daarvan tot Ekumeniese Teologie.
}

D Crafford

\author{
Abstract
}

Ecumenical Studies as a scientific discipline and its relation to ecumenical theology.

An effort is made to define ecumenism as a comprehensive process. A description is given of the specific character and contents of Ecumenical Studies as theological discipline as well as ecumenical theology as a particular approach to theology. Proposals of how each theological discipline can be practised from an ecumenical viewpoint are given. The article closes with a discussion of the relationship between Ecumenical Studies and ecumenical theology.

Die ekumene het hom in die twintigste eeu ontplooi as 'n omvattende beweging'. In die eerste plek was daar 'n groeiende teologiese besinning oor die eenheid as wesenskenmerk van die kerk. Hiertoe het die insigte van die Bybelwetenskappe en die dogmatiese besinning grootliks bygedra. Die konsensus waartoe gekom is, is dat die kerk as liggaam van Christus wesenlik een is; dat die eenheid begrond is in die goddelike Drie-eenheid en dus 'n gegewe werklikheid; dat die realiteit van die verskeurdheid van die kerk nie aanvaarbaar is nie, maar sonde is; dat die gebroke eenheid weer herstel behoort te word en dat kerke 'n roeping het om mee te werk aan die herstel en sigbaarmaking van die eenheid van die kerk ${ }^{2}$.

In die tweede plek het die ekumene ontvou as ' $n$ historiese beweging wat vergestalt is in die samewerking op sendinggebied, die totstandkoming van die Wêreldraad van Kerke, die evangeliese beweging en die vorming van 'n groot aantal denominasionele ekumeniese liggame ${ }^{3}$. Derdens het ons te doen met die ekumene in praktyk wat bestaan uit dialoog tussen kerke en gemeentes; samewerking op 'n groot verskeidenheid van terreine asook praktiese onderhandelinge met die oog op kerkvereniging op talle plekke in die wêreld.

Al hierdie ekumeniese aktiwiteite het gekulmineer in 'n magdom van kennis en inligting wat roep om gesistematiseerde en wetenskaplike bestudering. So het die vakgebied Ekumenika ontstaan as 'n relatief jong studierigting. Die vakgebied hou hom besig met die bestudering van die ekumene in 'n omvattende sin. Daar bestaan egter nog baie vrae oor die bestaansreg van die vak asook oor die aard, wese en inhoud daarvan. Daar is ook onsekerheid oor die ensiklopediese plek van die vakgebied en pleidooie word gelewer om dit te huisves by Ekklesiologie, Sendingwetenskap, Dogmatiek of selfs by Praktiese Teologie. In die artikel wil ons poog om groter helderheid te bring oor Ekumenika as wetenskaplike studieveld.

Naas die studieveld Ekumenika, gaan daar ook alhoemeer pleidooie op vir 'n ekumeniese benadering van die teologie ${ }^{4}$. Die ingewikkelde teologiese, hermeneutiese, ekologiese, etiese en praktiese vraagstukke in die wêreld van ons tyd roep om so 'n benadering. Ons wil dus ook nagaan wat onder ekumeniese teologie verstaan word en wat die verhouding daarvan moet wees tot die vakgebied Ekumenika.

Die min suksesse en die vele probleme wat opgeduik het in die ekumeniese beweging 
het aanleiding gegee tot 'n pessimisme oor die toekoms van die ekumeniese beweging ${ }^{5}$. Dit raak egter nie die noodsaaklikheid vir die beoefening van Ekumenika as vakgebied nie en ook nie die dringendheid vir 'n ekumeniese benadering in die teologie nie. Al gaan die kerk van Christus die 21 ste eeu tegemoet as 'n verdeelde en verskeurde liggaam, mag die strewe tot versoening en heling nooit verslap nie! Die ekumeniese probleem het so verdiep dat dit menslik totaal onmoontlik lyk om dit te ontrafel. Elke skeuring van die verlede is niks minder nie as ' $n$ venwonding van die liggaam van Christus wat roep om genesing. Ons moet egter on thou dat die ekumene ' $n$ daad is van geloof en hoop. Dit is gegrond op die vaste wete dat Christus self sy kerk in stand hou en dat die Heilige Gees versoenend, helend en verenigend aan die werk is in die verskeurde liggaam. Daarom bly die ekumene steeds die roeping waarmee die kerk ook die een-en-twintigste eeu moet tegemoetgaan.

\section{Wat is ekumene dan?}

Dit is nodig om tot ' $n$ duidelike definisie te kom van wat met die begrip ekumene bedoel word. Dit is egter geen eenvoudige probleem nie, want elkeen van die groot kerklike tradisies het 'n eie definisie van die begrip.

Vir die Rooms Katolieke Kerk beteken ekumene in wese ' $n$ terugkeer na die universele kerk van Rome wat ook inhou die erkenning van die pous as die enigste hoof van die liggaam van Christus op aarde. Ekumene beteken dus dat "die afgeskeie broeders" weer na die "moeder" moet terugkeer" ${ }^{6}$.

Die Oosterse Ortodokse Kerk glo ook dat hy die voortsetting is van die eens onverdeelde kerk van die apostels. Sowel die Rooms-Katolieke as die Protestantse afskeidings word gesien as ' $n$ breuk met die ware kerk. Ekumene word dus gesien as die handeling waardeur die ander tradisies op een of ander wyse met die Ortodokse Kerk as sentrum in verband gebring kan word'.

Die Protestantisme het vrede gemaak met die idee van kerklike pluriformiteit en soek ekumene eerder in 'n geestelike verbintenis met Christus as hoof van die kerk. Tog word meestal aanvaar dat die eenheid sigbaar gerealiseer moet word deur vorme van gesprek, samewerking en bes moontlik uiteindelike eenwording. Oor die vraag van hoe dringend strukturele eenwording is, bestaan daar ook groot verskil van mening binne die Protestantisme. Te midde van die verskeidenheid van standpunte moet ons nou kom tot ' $n$ werkdefinisie van wat ons vir die doel van hierdie artikel en vir die praktiese beoefening van die ekumene met die begrip bedoel. Die definisie moet heenwys na die vergestalting van die universele liggaam van Christus op aarde maar moet ook ruimte laat vir die beoefening van die ekumene in 'n plaaslike gemeente of gemeenskap. Dit moet dus die ekumeniese roeping van die kerk in hierdie gebroke wêreld duidelik omskryf.

Vir bogenoemde doel neem ons met enkele kleiner wysigings die baie bruikbare definisie oor van CS Kotze soos geformuleer in sy proefskrif ${ }^{2}$. Byvoegings tot die definisie word hier kursories gedruk: Onder ekumene moet verstaan word daardie beweging waarin elke gelowige en elke kerk as deel van die liggaam van Christus op aarde, die ander, aan die anderkant van die taalgrens, kulturele grens, landsgrens, konfessionele grens, kleurgrens en ideologiese grens soek, omdat hy met hom in gesprek wil tree, met hom versoen wil wees, met hom wil saamwerk, met hom saam 
die waarheid van die Skrif wil verstaan en per slot van sake met hom een wil wees, omdat hy sy eie kerk-wees en lid-wees van die liggaam van Christus ook in die ander as kerk erken en deur die ekumene 'n getuienis wil lewer aan die wêreld.

Die uitgangspunt van hierdie definisie is dat die kerk die een liggaam van Christus op aarde is wat hoewel dit baie lede het, tog 'n sigbare eenheid moet vertoon tot ' $n$ getuienis vir die gebroke wêreld. Die ekumene kan as 'n "beweging" beskryf word omdat die kerk geroepe is om ernstig daarna te strewe om die eenheid wat tussen gelowiges deur die Gees gesmee is, te handhaaf (Ef 4:3). Die strewe en die beweging kom egter nooit tot ' $n$ einde in hierdie onvolmaakte bedeling nie. Dit is ' $n$ beweging wat sal duur tot by die voleinding. Die ekumene bestaan uit 'n soeke na die "ander" gelowige of kerk anderkant die begrensinge wat gelowiges en kerke van mekaar skei. Die opsoek van die medegelowige en die saam werk en saam leef met hom word immers geïmpliseer deur die beeld van die een liggaam waarvan die lede in afhanklikheid van mekaar en tot aanvulling van mekaar bestaan. In die soeke na die ander moet grense oorskrei word. Skeiding is ongelukkig deel van die sondige werklikheid waarbinne ons lewe. Die ekumene wil grense oorskrei ten einde mense wat by mekaar hoort by mekaar uit te bring. Die ekumene het nie ten doel om taal en kulturele verskille tussen mense uit te wis nie. Dit wil met erkenning van die verskille juis voorkom dat dit skeidsmure word wat gemeenskap tussen mense onmoontlik maak. Die werklikheid van kontekstuele, kulturele, rasse, ideologiese en konfessionele verskille tussen mense kan nie ontken word nie. Dit is deel van die ryke verskeidenheid van God se skepping. Die ekumene probeer slegs voorkom dat die sinvolle verskeidenheid nie tot ' $n$ sondige verskeurdheid binne die liggaam van Christus verval nie.

Die doel van die ekumene moet omskryf word in konsentrasie sirkels van verskillende intensiteit. Die wydste sirkel is seker die van ' $n$ verkennende gesprek tussen vervreemde lede van die een familie van God. Die gesprek verdiep algaande met die doel om versoening te bewerk tussen mense en kerke wat vervreemd geraak het van mekaar. Die volgende sirkel is die van samewerking en gesamentlike optrede op verskillende terreine. ' $n$ Nog intenser vorm van samewerking is die gesamentlike soeke na die volle begrip van die waarhede van die Woord van God. Dit sluit in die gesamentlike ontdekking van die veelkantigheid van die waarheid van die Skrif, maar ook die korrektiewe wat op mekaar uitgeoefen kan word in die misverstaan en verdraaiing van die Skrif. Die mees intieme vorm van ekumene is as daar iets van ' $n$ geestelike ekumene beleef kan word by gesamentlike aanbidding en viering van die nagmaal. Hierdie eenheid wat so beleef word, kan dan selfs struktureel tot uitdrukking gebring word in skakelstrukture of eenwording tussen kerke. Die uiteindelike doel van die hele proses is om die mistieke liggaam van Christus as organisme so sigbaar volgens sy ware wese te laat funksioneer dat dit tot 'n getuienis kan wees vir die hele wêreld.

\section{Die vakgebied Ekumenika}

Die wetenskaplike studie van die ekumeniese proses kry gestalte in die vakgebied Ekumenika. Met die ontwikkeling van die ekumeniese beweging in die twintigste eeu, het die vakgebied as selfstandige studierigting ontstaan en geweldig gegroei in 
omvang ${ }^{9}$. In meeste teologiese Fakulteite word die belangrikheid en selfstandigheid van die vakgebied vandag erken.

Die vraag is of daar aan Ekumenika 'n selfstandige identiteit binne die teologiese wetenskap gegee kan word of loop die eenheid van die kerk soos 'n goue draad deur al die teologiese dissiplines? Die kerk funksioneer as 'n organisme op aarde wat mense tot bekering moet roep, gemeenskap tussen gelowiges moet bewerkstellig, diens van barmhartigheid moet verrig, moet getuig teen onreg en onderdrukking en tekens van die Koninkryk in hierdie gebroke wêreld moet oprig. Dit alles kan alleen doeltreffend geskied en tot eer van God indien die eenheidsbeeld in die funksionering van die kerk duidelik na vore kom. Die eenheid van die kerk is dus van belang vir alle teologiese dissiplines. Daar is egter ook behoefte om die grondslae, teologiese besinning, historiese verloop, suksesse en mislukkings van die ekumeniese proses wetenskaplik tot 'n eenheidstruktuur te verwerk ten einde 'n volledige beeld daarvan te probeer kry. Hierin lê die regverdiging vir Ekumenika as selfstandige vakgebied.

Ons konklusie is dus dat daar aan die een kant 'n behoefte is aan die ekumeniese beoefening van al die teologiese vakdissiplines ${ }^{10}$. Daarbenewens is daar egter vanwe die belangrikheid van die eenheidsgestalte en eenheidsfunksie van die kerk in 'n gebroke wêreld ook behoefte aan die konstruksie van Ekumenika as 'n selfstandige dissipline.

Indien Ekumenika as ' $n$ selfstandige dissipline beoefen behoort te word, is die volgende vraag wat die ensiklopediese plek daarvan dan moet wees? Omdat Ekumenika te doen het met die wese van die kerk as liggaam van Christus, is dit duidelik 'n onderafdeling van die ekklesiologiese groep van vakke. Dit het egter ook ' $n$ baie sterk dogmatologiese, diakonologiese en missiologiese komponent. Daar kan argumente aangevoer word om Ekumene te plaas in byna elkeen van bogenoemde vakgroepe. Die plasing daarvan in een vakgroep beteken egter dat bepaalde ander komponente verlore gaan. Daarom is dit verkieslik dat Ekumenika as ' $n$ bykomende selfstandige vakgebied in die teologiese Fakulteit gevestig word wat gebruik kan maak van die insette van die verskillende vakgroepe. Daar behoort verkieslik 'n vakspesialis te wees wat die los drade tot 'n eenheid integreer. Daarby kan die bibliologiese vakke insette lewer tot die Bybelse fundering van die eenheid en verskeidenheid binne die kerk; die dogmatologiese besinning oor die wese en roeping van die kerk kan gelewer word deur die dogmatologiese vakgroepe; die historiese vakke kan die geskiedenis van die ekumeniese beweging behandel en die missiologiese vakke kan die klem laat val op die noue verband tussen die sending van die kerk in die wêreld en die versameling van die volk van God uit al die nasies.

So bied Ekumenika binne die teologiese fakulteit 'n uitstekende geleentheid vir interdissiplinère samewerking en die opbou van 'n dissipline wat gebruikmaak van die metodes van die totale teologiese wetenskap. Die eie aard van die vakgebied is egter daarin geleë dat dit te doen het met die grondslae, geskiedenis en gestaltegewing van die eenheid binne die verspreide dele van die een liggaam van Christus op aarde.

Aangesien 'n afsonderlike departement vir Ekumenika beswaarlik aan bestaande teologiese Fakulteite gevestig sal kan word vanweë finansiële probleme, kan die vak administratief geplaas word by Kerkgeskiedenis of Sendingwetenskap met gebruikmaking van insette uit ander vakgebiede. Daar behoort egter verkieslik 'n vakspesialis te wees wat die verspreide ekumeniese drade tot 'n eenheid kan saamvleg en wat leiding kan gee aan doktorale studente. 


\section{Die inhoud van Ekumenika}

Die inhoud van die vak sal bepaal word deur die perspektief van waaruit dit benader word. Vanuit die Bybelse perspektief sal die klem val op dit wat die Skrif leer oor die eenheid en verskeidenheid van die kerk. Vanuit die Dogmatiese perspektief sal die klem val op die prinsipiële vrae rondom die eenheid, katolisiteit en apostolisiteit van die kerk. Vanuit ' $n$ historiese perspektief sal die klem weer val op die geskiedenis van die ekumeniese beweging deur die eeue heen. Vanuit ' $n$ Missiologiese hoek sal daar weer besondere aandag gegee word aan die verhouding tussen sending en ekumene, die sendingbeweging en die ontwikkeling van die sendingbegrip in die ekumeniese denke. Vanuit die Praktiese Teologie sal daar weer meer aandag gegee word aan die praktiese beoefening van die ekumene op die verskillende vlakke van die kerklike lewe. Volgens die standpunt wat ek hierbo ingeneem het, is dit wenslik dat die vak Ekumenika opgebou moet word as ' $n$ interdissiplinêre eenheid waarin al bogenoemde perspektiewe gekombineer word.

In hierdie geval sal daar begin word met 'n inleidende verklaring van die begrippe ekumene, die ekumeniese probleem, eenheid en verskeidenheid en die ekumeniese roeping van die kerk. Vervolgens sal aandag gegee word aan die fundering van die ekumeniese roeping vanuit die Skrif, die Belydenisskrifte van die betrokke tradisie en vanuit teologies - dogmatiese besinning. Vervolgens sal die geskiedenis van die ekumene aan die orde moet kom. Dit sluit in die verhaal van skeuring en heling in die kerk in die vroeë tydvak, die middeleeue, die Reformasie, die agtiende eeu, die negentiende eeu met insluiting van die sendingbeweging en ten slotte die ontplooiing van die moderne ekumeniese beweging van die twintigste eeu. Die geskiedenis van die ekumene van ' $n$ besondere kontinent, of land of ' $n$ besondere kerk kan binne die historiese raamwerk meer intensief behandel word.

Die vierde deel van die inhoud van die vak het te doen met die ekumeniese praktyk. Hier moet riglyne gegee word vir die beoefening van institusionele, teologiese, geestelike en plaaslike ekumene. Hier kan ook die verskillende modelle vir die funksionering van die eenheid van die kerk ter sprake kom. In hierdie fase behoort studente ook blootgestel te word aan ekumeniese ervaring en behoort hulle saam te werk aan ekumeniese programme en aksies.

Ons het gesien dat naas die behoefte aan Ekumenika as geïntegreerde vakgebied, daar ook ' $n$ behoefte is aan ' $n$ ekumeniese benadering in al die teologiese dissiplines.

\section{Wat is ekumeniese teologie?}

Ekumeniese teologie wil die hele openbaring vanuit 'n ekumeniese perspektief bekyk. Dit beteken dat nie net met die eie konfessie volstaan kan word nie, maar dat daar gesamentlik vanuit verskillende konfessies gesoek moet word na die totaliteit van God se heilsboodskap vir die wêreld. Op die wyse word konfessionele benaderinge toegelaat om mekaar te korrigeer en mekaar te verryk. Die bedoeling is om so tot 'n dieper insig van die Skrifboodskap te kom. Dit het belangrike implikasies vir die hermeneutiek. As die Skrif verstaan en verklaar word vanuit die verskillende situasies waarin mense hulle bevind, kan daar tot ' $n$ beter begrip gekom word van die omvattendheid van die heilsboodskap. 
Ekumeniese teologie is dus ' $n$ bepaalde benadering tot die teologie waarmee kerke saam op weg kan gaan tot ' $n$ beter verstaan van die openbaringsboodskap ${ }^{11}$. Dit vervang nie konfessionele teologie nie, maar vul dit aan, verryk en korrigeer dit. Juis daarom is dit ' $n$ noodsaaklike aanvullende benadering tot koniesslonele teologie ${ }^{12}$. Ekumeniese teologie hou dus in dat daar 'n ekumeniese benadering behoort te wees in die beoefening van al die teologiese dissiplines.

\section{Ekumeniese beoefening van Kerkgeskiedenis ${ }^{13}$}

In die beoefening van Kerkgeskiedenis is die versoeking baie groot om vas te val in konfessionele geskiedskrywing, dit wil sê die klem val eensydig op die eie denominasie. Daar moet egter onthou word dat die geskiedenis van die eie kerk nooit losgemaak kan word van die geskiedenis van die hele kerk as liggaam van Christus op aarde nie. Die katolisiteit van die kerk mag nie net bely word nie, maar moet tot sy reg kom in die kerkgeskiedskrywing. Enige konfessionele en kerkistiese geskiedskrywing doen dus afbreek aan die ekumeniese roeping van die kerk. In so 'n geval word begrip vir die universaliteit en katolisiteit van die kerk maklik verloor.

In 'n kerkistiese geskiedskrywing word die eie kerk dikwels verheerlik en ander kerke afgekraak. Dit neem nie in ag dat die Heilige Gees wat die totale liggaam van Christus besiel, ook ander kerke lei en dat Christus wat hoof van die kerk is, ook ander kerke regeer nie. Konfessionele geskiedskrywing ruk maklik sekere tydperke in die geskiedenis uit verband en oorbeklemtoon die bydrae van sekere figure wat met die eie kerk se geskiedenis te doen het. Eers as dit in die perspektief van die breë kerkgeskiedenis geplaas word, word die nodige balans verkry.

Daar is die versoeking om in leerplanne slegs die eie kontinent of land se geskiedenis te behandel. Afrika, Asië en Latyns-Amerika word dikwels aan die Sendinggeskiedenis oorgelaat. Dit is egter belangrik om ook die perspektiewe van ander kontinente op die geskiedenis te laat val. Alleen vanuit hulle perspektiewe sal begryp word dat eenheid nie volledig is as dit nie ook die armes, onderdruktes en gestremdes insluit nie ${ }^{14}$. So word begryp dat ekumenisiteit ook die stryd vir sosiale geregtigheid en ware gemeenskap tussen mense wat van mekaar verskil, insluit.

Dit word nie ontken dat daar ook ' $n$ noodsaaklikheid is om die eie kerk se geskiedenis te beskryf nie, maar dan moet dit altyd in verband en in wisselwerking met die geskiedenis van die Kerk as liggaam van Christus gesien word. 'n Ekumeniese benadering van die kerkgeskiedenis kan juis kerke help om nie strydpunte van die verlede so te verabsoluteer dat hulle in die hede geen kans het om by mekaar uit te kom nie. Die Ekumene moet Kerkgeskiedenis help om hierdie perspektief raak te sien.

\section{Dogmatiek in ekumeniese perspektief ${ }^{15}$}

Hoewel dit waar is dat teologie altyd ' $n$ konfessionele grondslag het, is dit tog ook die taak van die Dogmatiek om verskillende konfessionele perspektiewe met mekaar te vergelyk en in verband te bring. Ekumeniese Dogmatiek grens nie maar net die eie leerstellinge af teen dié van ander wat as vals beskou word nie, maar is ook bereid om soms verryk of gekorrigeer te word deur insigte vanuit ander konfessies. Ekumeniese 
Dogmatiek gaan nie uit van die standpunt dat hy alleen die volle waarheid in pag het nie (dit sou grens aan sektarisme), maar bely dat die waarheid vanuit verskillende konfessionele perspektiewe benader kan word. Daarom kan 'n ekumeniese dogmatiek help om die veelkantigheid van die waarheid raak te sien. Dit wil nie sê dat konfessionele verskille verdoesel of geignoreer moet word ter wille van die ekumeniese gesprek nie. Die sterk beklemtoning van eie konfessionele standpunte teenoor ander kan egter alle partye help om die grootheid van die geopenbaarde waarhede te begryp en kan ook lei tot die bou van brûe tussen verdeelde kerke. Skeiding en vyandigheid berus dikwels op misverstand en wanbegrip eerder as op werklike konfessionele verskille.

Die Apostolicum is die basis vanwaar ekumeniese Dogmatiek uitgaan. Dit herinner alle denominasies aan die sentrale belydenis dat Jesus die Here is. Dit roep die kerk op tot ' $n$ besef van sy katolisiteit, apostolisiteit en eenheid. Die kerk is ekklesia - die plek waar mense saamgeroep word uit alle volke, tale en rasse. Dogmatiek moet duidelik uitspel dat die een God besig is om deur die Heilige Gees die een kerk as liggaam van Christus te versame ${ }^{16}$. As die beoefening van Dogmatiek ' $n$ enge kerkisme tot gevolg het, is dit in stryd met die ekumeniese roeping van die kerk.

\section{Praktiese Teologie in ekumeniese perspektief}

Wanneer met die teorie en praktyk van kerklike handelinge gewerk word, is dit ook van groot belang om bedieninge soos die prediking, pastoraat, liturgie en kerklike bestuur van verskillende tradisies met mekaar te vergelyk. Dit kan alleen dien tot verryking van die eie bediening indien dit bestudeer word in vergelyking met bedieninge van ander tradisies. Op dié wyse kan onderlinge bevrugting plaasvind en ' $n$ beter begrip ontwikkel van die universele bediening wat Christus aan sy kerk op aarde gegee het.

Mense leef in verskillende kontekste en dit is in ' $n$ groot mate bepalend vir die kerklike praktyk. Mense in Afrika, Asië en Latyns Amerika wat worstel met armoede en onderontwikkeling, lê groot klem op die bediening aan armes en onderdruktes. Dit is 'n perspektief wat ' $n$ middelklas Europese, Amerikaanse of selfs blanke Suid Afrikaanse kerk uit die oog kan verloor. Die perspektief vanuit verskillende kontekste is dus baie belangrik.

Indien die kerklike bediening benader word vanuit die perspektief van ' $n$ verskeidenheid van konfessionele benaderinge, kan ' $n$ mens die naaste kom aan die een omvattende bediening wat Christus aan sy liggaam op aarde toevertrou het. Die versnippering van hierdie bediening in soveel opponerende bedieninge is ' $n$ tragedie wat deur ' $n$ ekumeniese benadering reggestel behoort te word.

\section{Ekumeniese Missiologie (Sendingwetenskap)}

Die uitgangspunt van die Sendingwetenskap is dat God sy eniggebore Seun in die wêreld gestuur het om vir Hom ' $n$ volk op aarde te versamel wat sy liggaam is wat deur die Heilige Gees besiel en gelei word om die instrument te wees waardeur die een verlossingsboodskap na die hele wêreld uitgedra moet word. Sending is dus in wese 'n ekumeniese opdrag omdat dit gegee is aan die hele kerk van Christus op aarde. 
Daarom moet ook in die sendingpraktyk altyd gesoek word na 'n ekumeniese benadering. Dit gaan nie in sending om proseliete makery nie, maar om die koms van die Koninkryk van God in die wêreld.

Die verabsolutering van kerkplanting as doel van die sending het gelei tot oneindige duplisering van kerke op die sendingveld. (Vergelyk byvoorbeeld die drie Afrikaanse Gereformeerde Kerke wat talle verskillende Dogterkerke geplant het). Kerkplanting kan alleen positief beoordeel word as dit in diens van die Koninkryk en van die een liggaam van Christus op aarde staan en nie as dit lei tot kerklike versplintering nie. Die sending waardeur kerke geplant is wat vyandig en in opposisie tot mekaar bestaan, is niks anders nie as tot beskaming van die Hoof van die liggaam. Daarom is sowel die ekumeniese beoefening van die Sendingwetenskap as ekumeniese beoefening van die sendingpraktyk van die grootste belang.

In 'n publikasie getiteld Oecumenische inleiding in de Missiologie onder redaksie van FJ Verstralen en andere word die hele Missiologie in ekumeniese perspektief geplaas en die doel daarvan soos volg beskryf: "Vanuit een geloofsinteresse in de betrokkenheid van de wereld op het koninkryk van God bestudeert de Missiologie de beweeglijkheid van het Christendom te midden van culturen, godsdiensten, sociaal-economische systemen en politieke institusies. Concentratie op de problematiek van de communicatie van het evangelie aan mensen uit "alle volkeren" is daarin even belangrijk als het kritisch doordenken van de theologische begrippen waarmee de geloofsinteresse levend wordt gehouden. Gezien de situatie van het wereldchristendom is een oecumenische beoefening van het vak onvermijdelijk en noodzakelijk" ${ }^{17}$.

\section{Ekumeniese beoefening van die Bybelse vakke ${ }^{18}$}

Ook in die beoefening van die Ou Testament en die Nuwe Testament is die ekumeniese perspektief van groot belang. Die Bybel is 'n boek met ' $n$ universele boodskap wat geldig is vir alle volke en alle tye. As die boodskap van die Bybel net vir een konteks of een tyd opgeëis word, word dit meesal verskraal of eensydig uit verband getrek. Toe die Bybel gebruik is om apartheid te regverdig, was dit ' $n$ vereensydiging van die boodskap van volkereverskeidenheid met verwaarlosing van die eenheid van die kerk ten spyte daarvan. As tans in bevrydingsteologie alle klem val op bevryding uit armoede en onderdrukking, word die boodskap van die Skrif ook vereensydig met verwaarlosing van die boodskap van verlossing uit sonde. Alleen as mense vanuit verskillende tye en verskillende kontekste na die Skrif gaan om antwoorde vir hulle besondere probleme daar te vind, kan ons uit die verskeidenheid van antwoorde uiteindelik kom tot die volle antwoord vir alle tye.

Daar is geen manier om die hermeneutiese vraagstuk op te los anders as deur 'n ekumeniese benadering tot die Skrif nie. Mense benader die Bybel vanuit verskillende kulturele, konfessionele, ideologiese en teologiese agtergronde. Daarom word die boodskap van die Bybel op verskillende maniere verstaan, uitgelê en toegepas. Alleen wanneer die verskillende benaderinge met mekaar in gesprek tree, kan hulle bevrugtend en korrektief op mekaar inwerk. Dele van die boodskap wat in een benadering verwaarloos word, word weer in 'n ander sterk beklemtoon. Alleen vanuit 'n ekumeniese perspektief kan die volle waarheid van God se geopenbaarde Woord tot ons 
spreek. Daarom is die interkerklike gesprek oor die Bybel van die grootste belang vir die verstaan van die boodskap. Daarom behoort eksegese ook nooit in isolasie bedryf te word nie.

In Suid-Afrika kan begrippe soos versoening, geregtigheid, bevryding en vrede alleen in hulle volle omvang begryp word, as die lig van die Skrif vanuit 'n ekumeniese perspektief daarop val. Daarom is interkerklike gesprek oor hierdie aktuele begrippe vir ons konteks en tyd van die grootste belang.

Dele van die Bybel word reeds gelees in byna 2000 tale wat deur $90 \%$ van die mense op aarde gepraat word. Vanweë die eenheid van die verlossingsboodskap van die Bybel, behoort die boek ' $n$ verenigende rol onder gelowiges te speel. Die feit dat dit in die geskiedenis dikwels ' $n$ verdelende rol gespeel het, kan alleen maar toegeskryf word aan die verduisterende rol van die sonde.

\section{Die verband tussen Ekumenika en ekumeniese teologie}

Waar ekumeniese teologie ' $n$ bepaalde benaderingswyse tot die teologie is, is Ekumenika ' $n$ vakgebied in eie reg wat die ekumeniese proses prinsipieel fundeer, histories beskryf en prakties begelei. Dit het te make met die teorie, geskiedenis en praktyk van die ekumene.

Die ekumeniese benadering tot die teologie vorm die basis van waaruit die vakgebied Ekumenika groei. 'n Ekumeniese bewustheid stel elke ander teologiese dissipline in staat om 'n positiewe bydrae tot Ekumenika te kan lewer. Om die vakgebied egter in 'n sistematiese wetenskaplike geheel op te bou, is ' $n$ vakspesialis nodig met kennis van die verskillende onderafdelings van die studieveld. Omdat Ekumenika oor al die teologiese studievelde heen sny, moet ruimskoots gebruik gemaak word van gespesialiseerde kennis en insigte van al die teologiese vakdissiplines.

\section{NOTAS}

1. Vergelyk R Rouse en SC Neill, A history of the Ecumenical Movement, 1517-1948, London 1954.

2. WG Rusch, Ecumenism. A Movement toward Church unity, Philadelphia 1985, 1-18.

3. WG Rusch, a.W., 1-34.

4. Vergelyk A König se pleidooi vir die beoefening van ekumeniese teologie in IH Eybers, A König en JA Stoop. Inleiding in die Teologie, Pretoria 1982.

5. F Klostermann, "Zukunft und Ziel der Okumenischen Bewegung: skeptische überlegungen eines katholischen Theologen", Evangelische Theologie 41 (1981), 309.325.

6. Vergelyk die Dekreet oor Ekumenisme soos opgeneem in: WM Abbott (Ed), The documents of Vatican II, Londen 1966, 336-367.

7. J Madey, "Der Beitrag der Orthodoxie zur "Okumene", in: Handbuch der Ökumenik, Band II, Paderborn 1986, 169-214. 
8. CS Kotze, Die Ned Geref Kerk en die ekumene, 1780-1910. Doktorale proefskrif, Stellenbosch, 1978.

9. S Amirtham, HS Cyris en CHS Moon, The teaching of Ecumenics WCC. Geneva 1987.

10. DHM Davies, Towards an ecumenical theology and a united church. Grahamstown 1948 (Rhodes University College. Inaugural lectures).

Ecumenical terminology. 1975. World council of Churches, Kent.

11. Peter Lengsfeld, Ökumenische theologie. Ein arbeitsbuch. Kohlhammer, 1980.

12. PS Minear, "Ecumenical Theology: Profession or Vocation?, Theology Today, Vol 33 (1978) 66-73.

13. TV Philip, "Church History in Ecumenical Perspective" in S Amirtham en CHS Moon, The teaching of Ecumenics, 42-53.

14. TV Philip, a.w., 4.

15. A Geense, "Teaching Sistematic theology ecumenically" A Amirtham en CHS Moon, a.w., 54-68.

Karl Hertz, "An investigation of ecumenical theology" Mid-Stream 19 (1980) 404-416.

16. A Geense, a.w., 54 .

17. FJ Verstralen (Red), a.w., 23.

18. John Mbiti, "An Ecumenical Approach to teaching the Bible" in S Amirtham en CHS Moon, a.w., 30-37. 